\title{
THE RELATION BETWEEN PRODUCTIVITY AND SPECIES DIVERSITY IN TEMPERATE-ARCTIC MARINE ECOSYSTEMS
}

\author{
Jon D. Witman, ${ }^{1,6}$ Mathieu Cusson,, 27 Philippe Archambault,${ }^{3}$ Andrew J. Pershing, ${ }^{4}$ and Nova Mieszkowska ${ }^{5}$ \\ ${ }^{1}$ Department of Ecology and Evolutionary Biology, Box G-W, Brown University, Providence, Rhode Island 02912 USA \\ ${ }^{2}$ School of Biology and Environmental Science, University College Dublin, Belfield, Dublin 4 Ireland \\ ${ }^{3}$ Institut des Sciences de la Mer de Rimouski (ISMER), Université du Québec à Rimouski, 310 Allée des Ursulines, CP 3300 Rimouski, \\ Québec G5L $3 A 1$ Canada \\ ${ }^{4}$ University of Maine and Gulf of Maine Research Institute, 350 Commercial Street, Portland, Maine 04101 USA \\ ${ }^{5}$ Marine Biological Association of the UK, Citadel Hill, Plymouth PL1 2PB United Kingdom
}

Abstract. Energy variables, such as evapotranspiration, temperature, and productivity explain significant variation in the diversity of many groups of terrestrial plants and animals at local to global scales. Although the ocean represents the largest continuous habitat on earth with a vast spectrum of primary productivity and species richness, little is known about how productivity influences species diversity in marine systems. To search for general relationships between productivity and species richness in the ocean, we analyzed data from three different benthic marine ecosystems (epifaunal communities on subtidal rock walls, on navigation buoys in the Gulf of St. Lawrence, and Canadian Arctic macrobenthos) across local to continental spatial scales $(<20$ to $>1000 \mathrm{~km})$ using a standardized proxy for productivity, satellite-derived chlorophyll $a$. Theoretically, the form of the function between productivity and species richness is either monotonically increasing or decreasing, or curvilinear (hump- or U-shaped). We found three negative linear and three hump-shaped relationships between chlorophyll $a$ and species richness out of 10 independent comparisons. Scale dependence was suggested by more prevalent diversity-productivity relationships at smaller (local, landscape) than larger (regional, continental) spatial scales. Differences in the form of the functions were more closely allied with community type than with scale, as negative linear functions were restricted to sessile epifauna while hump-shaped functions occurred in Arctic macrobenthos (mixed epifauna, infauna). In two of the data sets, (St. Lawrence epifauna and Arctic macrobenthos) significant effects of chlorophyll $a$ co-varied with the effects of salinity, suggesting that environmental stress as well as productivity influences diversity in these marine systems. The co-varying effect of salinity may commonly arise in broad-scale studies of productivity and diversity in marine ecosystems when attempting to sample the largest range of productivity, often encompassing a coastal-oceanic gradient.

Key words: Atlantic Ocean; Canadian Arctic; Gulf of St. Lawrence; macroecology; marine benthos; spatial scaling; species diversity theory; species energy theory.

\section{INTRODUCTION}

It is widely recognized that one of the central goals of ecology is to explain contemporary patterns of species diversity. Species-energy theory represents one class of hypotheses that has received a lot of attention recently for explaining patterns of diversity over large spatial scales. It posits that species richness is a function of some form of energy variables such as evapotranspiration (Wright 1983, Currie 1991), temperature (Rosenzweig 1995), or productivity (Brown 1981, Hawkins et al. 2003a,b). Statistical analyses of a wide range of terrestrial taxa confirm the importance of energy as a

Manuscript received 2 August 2007; revised 18 March 2008; accepted 7 April 2008; final version received 5 May 2008. Corresponding Editor (ad hoc): C. W. Cunningham.

${ }^{6}$ E-mail: Jon_Witman@brown.edu

${ }^{7}$ Present address: Département des sciences fondamentales, Université du Québec à Chicoutimi, 555 boulevard de l'Université, Chicoutimi, Québec G7H 2B1 Canada. driver of patterns of species richness on local-continental spatial scales. For example, $80-92 \%$ of the diversity of North American taxa of trees, amphibians, reptiles, and non-volant mammals was explained by potential evapotranspiration (Currie 1991). A recent review of the topic indicated that levels of water-energy relationships predicted plant species richness in over $60 \%$ of the studies (Hawkins et al. 2003b).

Multiple mechanisms may account for a positive influence of productivity on species diversity; several are associated with the increase in the number of individuals occurring when reproduction is enhanced at higher resource supply (Wright et al. 1993). Species diversity may increase with the number of individuals as extinction rates from demographic stochasticity are lowered at high population size (May 1974). Diversity also increases as a by-product of productivity since the proportion of rare species increases with the number of individuals in a community (Preston 1962). Speciation rates are thought to increase with the number of 
individuals as well (Wright 1983). Finally, species richness may increase with productivity if the heterogeneity of the productivity resource increases with the magnitude of productivity (Rosenzweig 1995). This enables niche-based resource partitioning on different aspects of the resource spectrum, thereby increasing diversity. Alternatively, species diversity may decrease with productivity due to the effects of competition if one species utilizes most of the productivity and outcompetes others (Rosenzweig and Abramsky 1993).

Many explanations for the descending limb of the hump-shaped form of the productivity-diversity relationship in plant communities invoke the effects of competitively dominant species decreasing diversity at high productivity, despite Grime's (1973) original model emphasizing the limiting effects of environmental stress. Huston (1999) and Kondoh (2001) linked productivitydiversity and disturbance-diversity relationships in the dynamic equilibrium model, asserting that the form of the disturbance-diversity relationship changes at different levels of productivity. Recently, Michalet et al. (2006) argued that positive interactions (facilitation) in high-stress environments can explain why diversity peaks at intermediate levels of environmental stress or productivity, asserting that biotic interactions influence both ascending and descending limbs of the common hump-shaped model.

Does productivity influence species richness in marine ecosystems as it does on land? It is difficult to answer this question as much less is known about influence of productivity on diversity in marine than in terrestrial systems. This is surprising given that the ocean is the largest continuous habitat on earth, encompassing a broad spectrum of primary productivity and species richness. As on land, initial studies of this relationship used indirect correlates of productivity, such as ocean depth, rather than direct measures. A hump-shaped pattern emerged when species richness was plotted as a function of depth (Rex 1981, Rosenzweig and Abramsky 1993). Low molluscan diversity at the end of the depth gradient (abyssal plain) may result from extremely low productivity (Rex 1981). At the taxonomic level of genera, the number of coral genera and ocean temperature were related, suggesting that a form of environmental energy was driving coral diversity (Fraser and Currie 1996). Striking latitudinal gradients in molluscan diversity in the Pacific were significantly related to sea surface temperature, which Roy et al. (1998) interpreted as consistent with species energy theory. There may be no effect of productivity on diversity, such as in marine pelagic diversity, which is predicted by temperature (Rutherford et al. 1999, Worm et al. 2005). A humpshaped relationship occurred for other pelagic forms such as procellariform sea birds on regional spatial scales (Chown and Gaston 1999).

One of the first experimental tests of the mechanisms underlying potential productivity-diversity relationships in the sea found that both algal and invertebrate species richness increased in nutrient enriched habitats compared to controls (Hall et al. 2000). Jara et al.'s (2006) experiments revealed similar results, but only at an oligotrophic site. In innovative manipulations of nutrients and consumers at one site in the Baltic and one in the Western Atlantic, Worm et al. (2002) demonstrated that consumer and resource effects on algal diversity were interactive, resulting in a hump-shaped relationship between these variables and diversity in rocky intertidal communities, supporting aspects of the dynamic equilibrium model. Similar experimental tests of this model in subtidal epibiotic communities, have found only weak support (Jara et al. 2006) or no interaction (Svensson et al. 2007) between disturbance and productivity.

It is important to understand how processes driving patterns of species diversity vary with spatial scale in order to construct general theories of diversity (Ricklefs 1987, Whittaker et al. 2001). Indeed, Mittelbach et al. (2001), Chase and Leibold (2002), and Scheiner and Jones (2002) found that productivity-diversity relationships in non-marine communities are scale dependent. A meta-analysis of the literature from terrestrial and aquatic habitats indicated that for vascular plants, the percent of positive linear productivity-diversity relationships was highest on the largest continental-global spatial scales $(>1000 \mathrm{~km})$, while negative linear functions occurred only at local and regional scales (Mittlebach et al. 2001). Humped-shaped relationships were reported in $40-50 \%$ of the studies across local $(<20 \mathrm{~km})$ to continental scales and were most common in studies that spanned a range of community types.

To systematically dissect the effects of spatial scale, we analyzed productivity-species-richness relationships according to two components of scale, extent, and grain (Whittaker et al. 2005). The extent refers to the general area over which an observation is made while the grain is the contiguous area of a sampling unit or the scale which data are aggregated for analysis (see Wiens [1989] and Whittaker et al. [2001] for definitions). Understanding the role of the grain (or focus) and the extent as well as controlling the scale is needed for progress in biodiversity theory (Whittaker et al. 2005). The treatment of the scale in Mittelbach et al.'s (2001) metaanalysis considered variation in extent (Whittaker and Heegaard 2003). In this study, the effects of spatial grain on productivity-species-richness relationships were investigated from small grain at the scale of local sites to larger regional and continental grain. We use the terms scale and grain synonymously.

To search for general patterns in productivity effects on marine species richness, we investigated the relationship between productivity and species richness in epifaunal and infaunal benthic invertebrate communities of the northern hemisphere across local-continental spatial scales using a standard measure of productivity: chlorophyll $a$ (chl a) concentration. Analyses of productivity vs. richness relationships were conducted within each data set (i.e., subtidal epifauna, buoy 
epifauna, Arctic epifauna and infauna) to ensure consistency in taxonomic resolution. The questions we addressed were (1) Are there statistically significant relationships between productivity (chl $a$ ) and species richness in marine benthic communities? (2) If so, does the relationship vary across spatial scales from the grain of local sites $(<20 \mathrm{~km})$, to landscape $(\sim 20 \mathrm{~km})$, regional $(\sim 200 \mathrm{~km})$, and continental-global scales $(>1000 \mathrm{~km})$ ? Detecting variation in the relationship between productivity and diversity as a function of scale will help identify the scale at which causal processes operate.

\section{Methods}

\section{Productivity assessment}

The measure of productivity used here was satellitederived chlorophyll $a$ from the SeaWiFS sensor. With this technique, a sensor quantifies chlorophyll based on the greenness of the water. Chlorophyll $a$ is a proxy for the concentration of phytoplankton, and concentrations from SeaWiFS are highly correlated with in situ chlorophyll measurements (Gregg and Casey 2004). This is the only consistent chlorophyll data available for all study sites, facilitating comparisons between regions. For our analysis, we obtained daily images from NASA's Ocean Color Web (available online). ${ }^{8}$ Each image consists of an array of pixels, with each approximately $9 \times 9 \mathrm{~km}$ pixels containing the chlorophyll value for that day. SeaWiFS computes chlorophyll concentration based on light reflected by phytoplankton in the water. Thus, if an area of ocean is obscured by clouds, that pixel will be blank. Especially important at high latitudes, SeaWiFS can not make a measurement if the sun angle is too low. Thus, chlorophyll data are unavailable for the highest latitudes during the winter.

We first constructed monthly chlorophyll climatologies by averaging all observations collected in a given month at a given pixel over 1998-2004. Then, we extracted the monthly chlorophyll values from the pixel nearest the site (latitude and longitudes) for each study site. For several sites, the nearest pixel in a particular month contained no valid observations. In this case, we expanded the spatial area and computed the mean over a $3 \times 3$ pixel block, and if needed, a $5 \times 5$ pixel block. It was assumed that the seven-year average chlorophyll concentrations represented typical productivity conditions at the sites sampled although in some cases the sampling of species richness occurred before (Canadian Arctic) or after (St. Lawrence epifauna) the period that chlorophyll was measured. Satellite chlorophyll measurements can be problematic in areas of high sediment load (Siegel et al. 2005). While these issues will lead to uncertainty in the precise chlorophyll values, the satellite chlorophyll should provide a good indicator of relative phytoplankton abundance, both seasonally at a site and between sites (e.g., Thomas et al. 2003).

\footnotetext{
${ }^{8}\langle$ http://oceancolor.gsfc.nasa.gov/〉
}

\section{Species richness}

The three benthic ecosystems analyzed for general relationships between productivity and species diversity were (1) subtidal communities of sessile epifaunal invertebrates attached to vertical rock walls (Witman et al. 2004; J. D. Witman, unpublished data); (2) sessile epifaunal invertebrate communities attached to navigation buoys in the Gulf of St. Lawrence and estuary (P. Archambault, unpublished data); and (3) epifaunal and infaunal benthos of the Canadian Arctic (Cusson et al. 2007). Diversity was represented as the number of species (species richness) in all analyses. When the number of species was investigated at different spatial scales (e.g., 20, 200, and $1000 \mathrm{~km}$ ) stations were pooled and total richness was recalculated.

Regression analyses were performed separately for each ecosystem because the methods used to sample species richness $(S)$ differed by ecosystem. The effect of salinity, which was considered an important variable potentially explaining species richness in two data sets (Canadian Arctic; Cusson et al. [2007] and St. Lawrence epifauna) was evaluated by a two-step analysis. First, we extracted the residuals of species richness (observed log $S$ minus predicted $\log S$ ) obtained from a simple linear regression between log-transformed species richness and salinity. Second, we performed another simple regression analysis using these residuals regressed against chlorophyll $a$. This is the standard procedure to extract the effect of a covariate in a regression analysis (Sokal and Rohlf 1981). Both variables of chlorophyll $a$ and species richness were $\log _{10}$-transformed in all the regression analyses. Normality was verified using the Kolmogorov-Smirnov goodness-of-fit test (Zar 1999) and homoscedasticity was confirmed by the constant variance test (SigmaPlot 2004 ver. 9.01, Systat Software, Chicago, Illinois, USA). A significance threshold $\alpha=$ 0.05 was adopted for all statistical tests. In cases where significant polynomial (quadratic) and linear regressions of chlorophyll $a$ and species richness were obtained from the same data set, we used partial $F$ tests (Quinn and Keough 2002) to decide whether or not the second-order polynomial better fit the data than a first-order (linear) model. Residual analyses were not conducted on the subtidal epifaunal data since salinity at the sites did not vary from fully oceanic conditions (salinity $\geq 35$ PSU; J. D. Witman, unpublished data). The assessment of the prevalence of different functions by community type and scale was based on a total count of 10 possible relationships (i.e., all data prior to correcting for salinity; Fig. 2a-d, Fig. 3a, b, Fig. 4a-d). This eliminated any non-independence in the total caused by counting subsets or sets of data with salinity covariates.

\section{Subtidal epifaunal communities}

The diversity of subtidal rock wall communities was censused by standardized photographic techniques involving SCUBA diving to place a transect tape across rock walls at 10-15 $\mathrm{m}$ depth (Witman et al. 2004). 
TABLE 1. Stations (sites) included in the analysis.

\begin{tabular}{|c|c|c|c|}
\hline Region & $\begin{array}{l}\text { No. sites } \\
\text { per region }\end{array}$ & $\begin{array}{l}\text { Median observed } \\
\text { species richness } \\
\text { (range) per site } \dagger\end{array}$ & $\begin{array}{c}\text { Median } \\
\text { chlorophyll } a \\
\text { (range) per siteł }\end{array}$ \\
\hline \multicolumn{4}{|l|}{ Rock wall epifaunal communities } \\
\hline Gulf of Maine & 5 & $31 \S(25-41)$ & $2.7 \S(1.7-3.5)$ \\
\hline Iceland & 3 & $52 \S(49-55)$ & $2.7 \S(2.2-2.7)$ \\
\hline Channel Islands, United Kingdom & 3 & $72 \S(65-78)$ & $1.5 \S(1.3-1.8)$ \\
\hline \multicolumn{4}{|l|}{ St. Lawrence buoy epifauna } \\
\hline Estuarine zones & 25 & $4.2 \S(0-9)$ & $9.3 \S(5.4-24)$ \\
\hline Gulf zones & 86 & $10.4 \S(1-25)$ & $3.8 \S(0.8-11.4)$ \\
\hline \multicolumn{4}{|l|}{ Canadian Arctic } \\
\hline Hudson Bay ${ }^{1}$ & 61 & $4(1-37)$ & $0.6(0.3-2.7)$ \\
\hline James Bay ${ }^{2}$ & 17 & $13(1-34)$ & $9.6(2.7-17.3)$ \\
\hline Victoria Island $^{3}$ & 10 & $49(20-84)$ & $0.8(0.6-1.6)$ \\
\hline Beaufort Sea and Mackenzie Shelf ${ }^{4}$ & 101 & $16(1-81)$ & $8(1.5-11.2)$ \\
\hline Frobisher Bay, Baffin Island ${ }^{5,6}$ & 12 & $132(21-175)$ & $1.7(1.6-3.5)$ \\
\hline Ungava Bay $^{7}$ & 3 & $107(81-166)$ & $1.4(1-1.5)$ \\
\hline
\end{tabular}

Sources: 1, Atkinson and Wacasey (1989a); 2, Wacasey et al. (1976); 3, Atkinson and Wacasey (1989b); 4, Wacasey et al. (1977);

5, Wacasey et al. (1979); 6, Wacasey et al. (1980); 7, MacLaren MAREX Inc. (1978).

$\uparrow$ Also contains taxonomic groups that were not identified at the species level (e.g., Nemata).

\$ Obtained by SeaWifs data set. Units are $\mathrm{mg} / \mathrm{m}^{3}$.

$\S$ Mean value.

Twenty-five to $360.25-\mathrm{m}^{2}$ quadrats were photographed with a quadrapod camera framer at random marks along the tape. The number of sessile epifaunal species (sponges, sea anemones, soft corals, gorgonians, solitary corals, hydroids, tubiculous polychaetes, barnacles, attached bivalves, bryozoans, brachiopods, ascidians, etc.) was counted in each photo quadrat. Species down to $1 \mathrm{~mm}$ maximum body size were identified by projecting the high-resolution color slide of the quadrat onto a screen or by viewing it under a binocular microscope. The local scale $(<20 \mathrm{~km})$ consisted of a single site, such as a subtidal ledge, pinnacle, or side of an island (Table 1). Sites were in temperate-arctic regions of the North Atlantic Ocean located in the Gulf of Maine, USA, the Vestmann Islands off the southern coast of Iceland, and the Channel Islands of the UK (Fig. 1). At least three replicate sites were sampled for species richness in each region (Table 1). In the subtidal

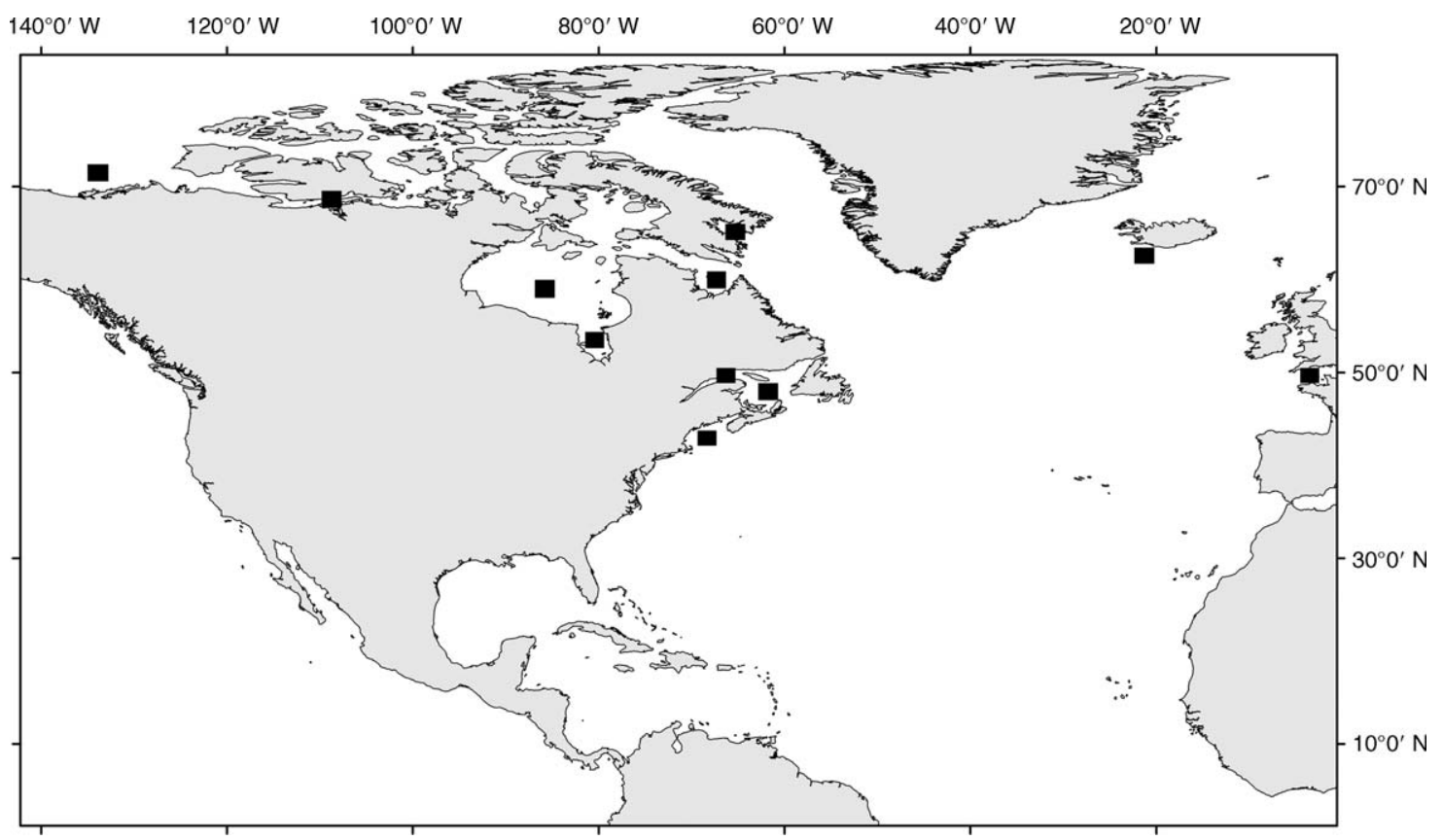

FIG. 1. Location of sampling areas (black squares) included in this study. Note that multiple replicate sites were sampled in each area; see details in Table 1. 
epifauna, regression analyses of chlorophyll $a$ vs. species richness were performed using total species richness obtained from species accumulation curves (Gotelli and Colwell 2001) constructed using Estimate S software (calculated as $S$ observed, Colwell 1997).

Since multiple factors are known to influence the diversity of local communities, the effect of consumers (sea urchins) on diversity was investigated in addition to productivity. Predation by sea urchins is known to reduce the species diversity of Atlantic (Witman 1985, Sebens 1986) and Pacific (Smith and Witman 1999) epifaunal communities. Photo quadrats with sea urchins from the Gulf of Maine often contained patches of bare substrate around sea urchins where they had clearly grazed away epifaunal invertebrates, and areas of coralline algal covered rock that is typical of urchin barrens (Witman 1985). Consequently, the effect of sea urchin grazing on species richness was evaluated by running the productivity-richness regressions with and without sites where sea urchins were abundant. The sites omitted were Halfway Rock, Mingo Rock, and Columbia Ledge (Gulf of Maine) where average densities of urchins (obtained from photo quadrats) ranged from 0.8 to 4.8 green urchins (Strongylocentrotus droebachiensis) per $0.25 \mathrm{~m}^{2}$.

\section{Epifaunal communities in the St. Lawrence system}

The diversity of epifaunal communities (hydroids, bivalves, barnacles, sessile and errant polychaetes, bryozoans, ascidians) inhabiting independent Canadian Coast Guard navigation buoys in the Gulf and Estuary (salinity $>20$ PSU) of St. Lawrence (Fig. 1) was sampled by two methods. The sampling took place in 2005 when the buoys were removed from the water in November-December and correspond to the species observed in the first $2 \mathrm{~m}$ from the surface. Buoys are removed every year and moored at the beginning of the spring season. First, on each of 109 buoys three $0.25-\mathrm{m}^{2}$ quadrats with 100 regularly spaced points were randomly placed to estimate the percentage cover of organisms. The method was adjusted on smaller buoys where three $0.625-\mathrm{m}^{2}$ quadrats with 25 points were used. Organisms under each point were recorded, and organisms seen but not recorded under a point were noted as present. Furthermore, an additional minute was spent at each quadrat recording any organisms present but not recorded (modified methods of Archambault et al. 2001). Voucher specimens of all species were collected to corroborate species identification in the lab (macroalgae excluded). The pooling of stations at regional spatial scales $(\sim 200 \mathrm{~km})$ was done using local ecological characteristics according to the zoogeographic subdivision from Brunel et al. (1998).

\section{Canadian Arctic benthos}

Species richness of the Canadian Arctic benthos was obtained from a literature review (Cusson et al. 2007). The sampling was done by standardized grabs (van Veen, Ponar, Eckman) of macrobenthic epifaunal and infaunal communities (retained on a 500- $\mu$ m mesh sieve) from marine and estuarine environments. A total of 239 stations were sampled (Table 1). The fauna was comprised of sponges, cnidarians, annelids, molluscs, arthropods, bryozoans, brachiopods, echinoderms, nemerteans, platyhelminthes, sipunculids, and others (Cusson et al. 2007). Each of the stations is represented by $1-10$ grabs (median, 4.5 ) for which the sampled areas were between 0.09 and $1.2 \mathrm{~m}^{2}$ (median, 0.25). Species richness was represented as the total number of species per station. Sampling stations were considered local sites. Most of the data used in this study were from technical reports of the Department of Environment and Fisheries and Oceans Canada, but data for some regions (Southern Davis Strait and Ungava Bay) are from published literature (Stewart 1983, Stewart et al. 1985). Data were obtained for diverse regions (Beaufort Sea and Mackenzie Shelf, Victoria Island, Hudson Bay, James Bay, Ungava Bay, Frobisher Bay, and Southern Davis Strait, Fig. 1) allowing a broader east-west comparison of benthic assemblages across the Canadian Arctic. Taxonomic names were checked and updated (e.g., for old or sister names) using data retrieved from the Integrated Taxonomic Information System on-line database (available online). ${ }^{9}$ Pooling of stations at different spatial scales $(20 \mathrm{~km}, 200 \mathrm{~km}, 1000 \mathrm{~km})$ was done using local ecological characteristics according to the zoogeographic subdivision of Canadian Arctic mollusc fauna from Lubinsky (1980) (with a subdivision for Frobisher and Ungava Bay) as well as the Arctic and the sub-Arctic regions described by Curtis (1975). Stations from Hudson Bay and from Beaufort Sea and MacKenzie Shelf were regrouped according to physical (depth and substratum type) and biological characteristics (species identity and biomasses levels) or similar community structure (e.g., Hudson Bay; P. Archambault, unpublished data from the MERICA program; short for "études des mers intérieures du Canada," studies of Canada's inland seas).

Further analyses were done on the Arctic data sets using the normalized expected number of taxa rarefaction method (Sanders 1968, as modified by Hurlbert 1971) to address the comparability of richness by standardizing abundances when sampling effort is not constant (see Gotelli and Colwell 2001). This method calculates the expected number of taxa, $E\left(S_{n}\right)$, in a reduced standardized sample of $n$ individuals selected from the given sample. For the rarefaction approach, a reduced number of individuals was chosen that took into account the lowest abundances at each station (local analyses: $E\left(S_{n}\right)$ with $n=150$, of which $13 \%$ of the stations have abundance below this number) or pooled stations for analyses at landscape $(n=325 ; 10 \%$ of stations have abundance below that number), regional $(n=600)$, and continental $(n=16000)$ scales.

\footnotetext{
${ }^{9}\langle$ www.itis.gov $\rangle$
} 
a) Local $<20 \mathrm{~km}$

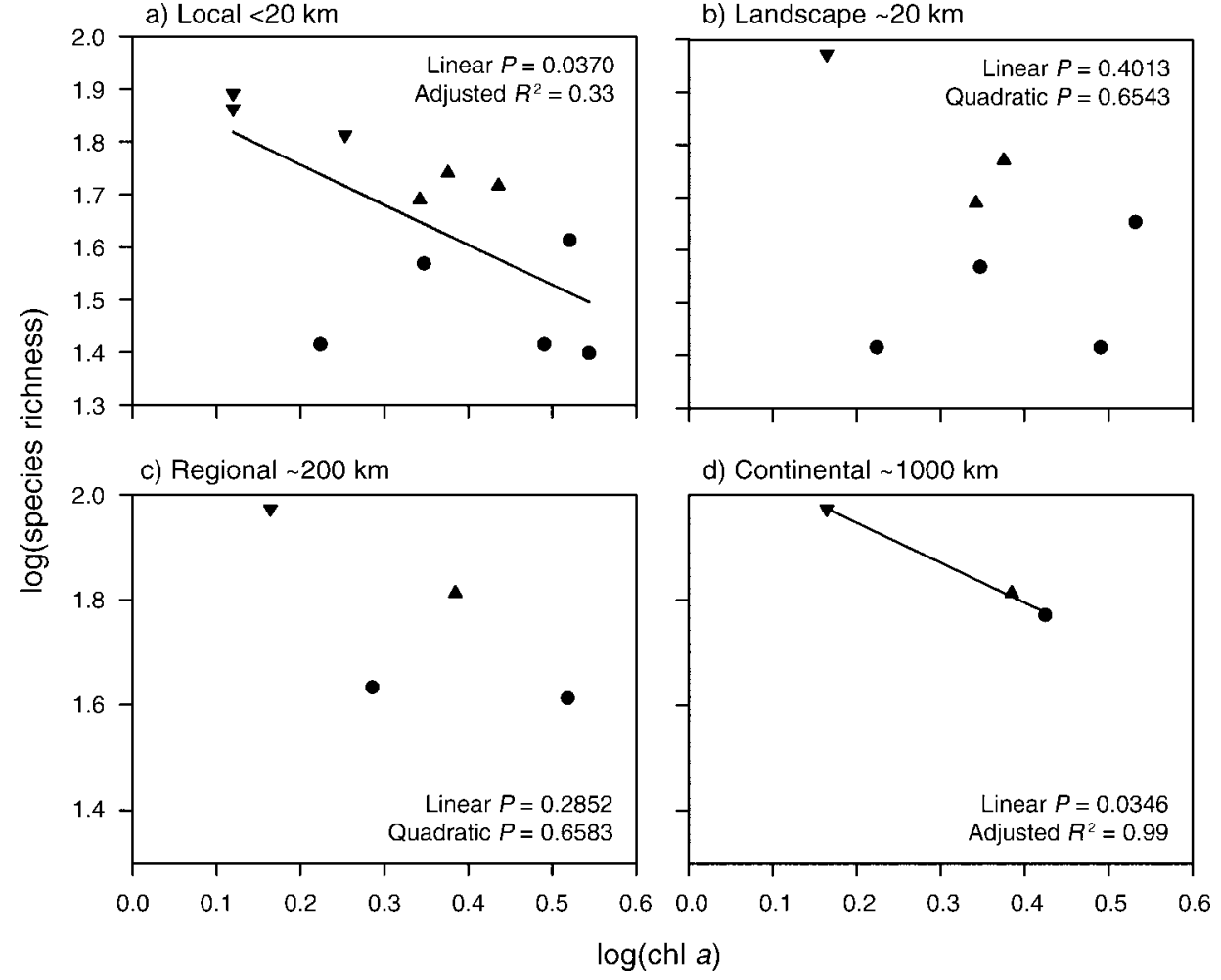

FIG. 2. Regression plots of estimated species richness $S_{\text {obs }}$ of subtidal epifaunal communities (rock walls at $10-15 \mathrm{~m}$ depth) against average chlorophyll $a$ at local $(<20 \mathrm{~km})$ to continental $(>1000 \mathrm{~km})$ scales. Circles represent sites in Gulf of Maine, triangles facing up represent Iceland data, and triangles facing down are from the Channel Island (United Kingdom) sites. See Table 2 for regression analyses.

\section{RESUlts}

\section{Subtidal epifauna}

A significant negative linear relationship occurred between species richness $(S)$ of epifaunal invertebrates and mean chlorophyll $a$ (chl $a$ ) at both local and continental spatial scales (Fig. 2a, d). Variability in chl $a$ explained $33 \%$ of the variability in $S$ at the local scale.
When the data from each site was pooled at landscape $(20 \mathrm{~km})$ and regional scales $(200 \mathrm{~km})$, no significant relationships were observed (Fig. 2b,c). The negative linear function observed at the local scale re-emerged at the continental scale with $99 \%$ of the variability in $S$ explained by chl $a$ (Fig. 2d). A comparison of linear regressions with and without sea urchin sites (regression graph not shown) suggested that urchin predation

TABLE 2. Results of significant linear and polynomial regression models shown in Figs. 2-4 to estimate species richness in the three marine ecosystems using the mean chlorophyll $a(\mathrm{chl} a)$ variable.

\begin{tabular}{|c|c|c|c|c|c|c|c|c|c|}
\hline \multirow[b]{2}{*}{ Plots } & \multirow[b]{2}{*}{ Type } & \multirow[b]{2}{*}{ Intercept } & \multirow[b]{2}{*}{ Chl $a\left(\mathrm{mg} / \mathrm{m}^{3}\right)$} & \multirow[b]{2}{*}{$(\mathrm{Chl} a)^{2}$} & \multirow[b]{2}{*}{ df } & \multicolumn{2}{|c|}{ MS } & \multirow[b]{2}{*}{$F$} & \multirow[b]{2}{*}{$P$} \\
\hline & & & & & & Model & $\overline{\text { Total }}$ & & \\
\hline Fig. 2a & $\mathrm{L}$ & $1.90 \pm 0.12$ & $-0.76 \pm 0.31$ & & 1,10 & 0.13 & 0.03 & 5.99 & 0.0370 \\
\hline Fig. 2d & $\mathrm{L}$ & $2.10 \pm 0.01$ & $-0.76 \pm 0.04$ & & 1,2 & 0.02 & 0.01 & 338.6 & 0.0346 \\
\hline Fig. 3a & $\mathrm{L}$ & $1.04 \pm 0.08$ & $-0.31 \pm 0.11$ & & 1,111 & 0.81 & 0.12 & 7.42 & 0.0075 \\
\hline Fig. 4a & Q & $1.18 \pm 0.05$ & $1.07 \pm 0.14$ & $-1.34 \pm 0.18$ & 2,207 & 7.57 & 0.33 & 29.44 & $<0.0001$ \\
\hline Fig. 4b & $\mathrm{Q}$ & $1.08 \pm 0.07$ & $0.99 \pm 0.16$ & $-0.73 \pm 0.24$ & 2,108 & 6.02 & 0.35 & 24.47 & $<0.0001$ \\
\hline Fig. $4 \mathrm{c}$ & $\mathrm{Q}$ & $1.94 \pm 0.10$ & $0.98 \pm 0.37$ & $-0.92 \pm 0.49$ & 2,14 & 0.35 & 0.13 & 3.72 & 0.0553 \\
\hline Fig. 4e & Q & $1.30 \pm 0.1$ & $1.62 \pm 0.36$ & $-2.08 \pm 0.31$ & 2,155 & 8.38 & 0.31 & 45.46 & $<0.0001$ \\
\hline Fig. 4f & $\mathrm{Q}$ & $0.82 \pm 0.12$ & $2.01 \pm 0.38$ & $-1.52 \pm 0.36$ & 2,59 & 2.90 & 0.29 & 14.91 & $<0.0001$ \\
\hline Fig. 4g & $\mathrm{L}$ & $0.84 \pm 0.22$ & $1.48 \pm 0.39$ & & 1,11 & 4.31 & 0.66 & 14.49 & 0.0034 \\
\hline Fig. $4 \mathrm{i}$ & $\mathrm{Q}$ & $-0.23 \pm 0.10$ & $1.53 \pm 0.35$ & $-1.43 \pm 0.30$ & 2,155 & 2.29 & 0.23 & 11.23 & $<0.0001$ \\
\hline Fig. $4 \mathrm{j}$ & Q & $-0.50 \pm 0.12$ & $2.01 \pm 0.38$ & $-1.50 \pm 0.36$ & 2,59 & 2.92 & 0.29 & 15.16 & $<0.0001$ \\
\hline
\end{tabular}

Notes: Species richness and chl $a$ were $\log _{10}$-transformed for use in the regression models. Type of regression: L, linear; Q, quadratic. Each regression coefficient $( \pm \mathrm{SE})$ and details of the ANOVAs are shown. Empty cells indicate that the variable was not included in the model. 


\section{Local $<20 \mathrm{~km}$}
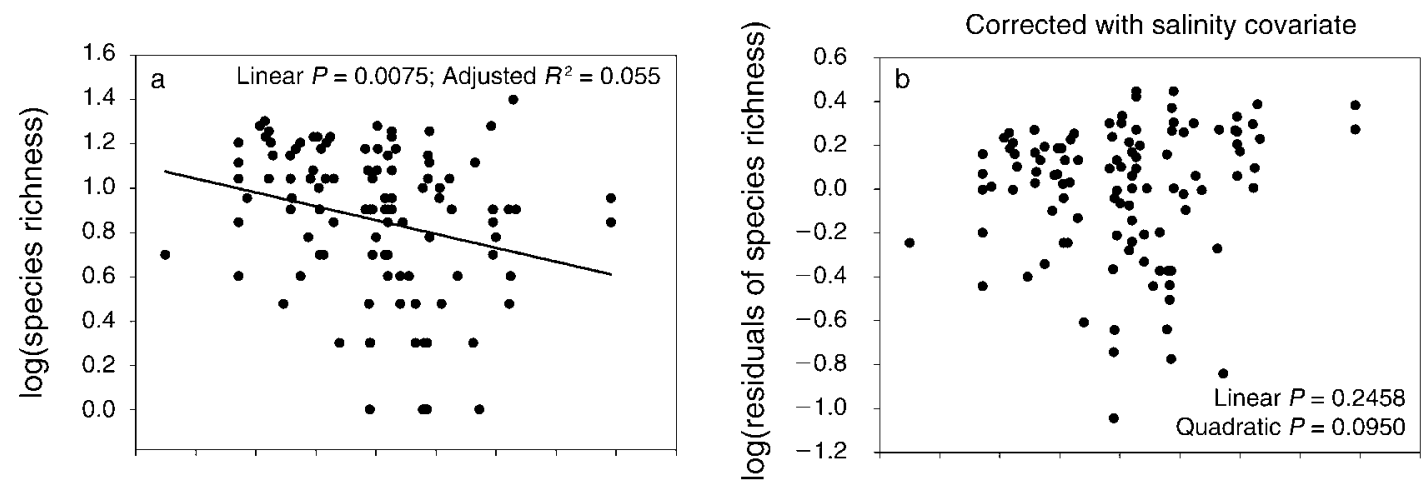

Regional $\sim 200 \mathrm{~km}$
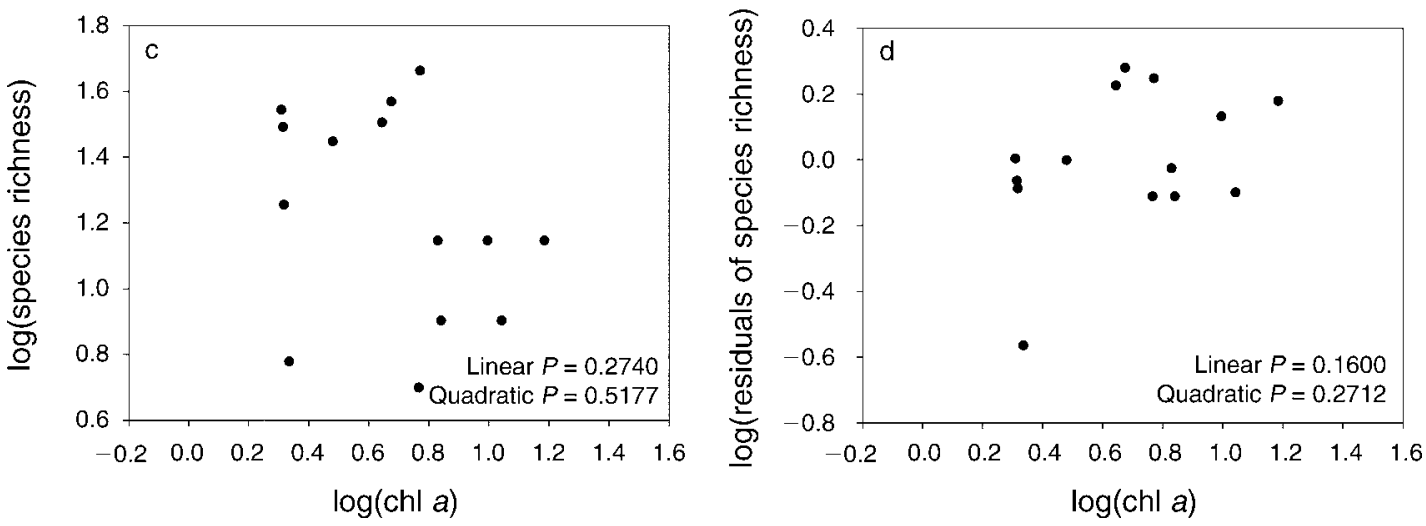

FIG. 3. Regression plots of species richness of the St. Lawrence Gulf and Estuary epifaunal invertebrates against average chlorophyll $a$ at local and regional $(\sim 200 \mathrm{~km})$ scales. Plots show separate analyses using species richness (a, c) without and (b, d) with a correction for salinity as covariate. Plots $\mathrm{c}$ and $\mathrm{d}$ are regressions of the residuals from the regression of $\log (\mathrm{species}$ richness) on salinity, against the average chlorophyll $a$ (see Methods). See Table 2 for regression analyses.

lowered invertebrate species richness and diminished the influence of productivity on local richness, since the regression coefficient $R^{2}=0.33$ calculated from all local sites (urchin and non-urchin) was lower than that of $R^{2}$ $=0.62$ (urchin sites excluded). The improved fit of the linear regression model when urchin sites were excluded resulted from the elimination of three of the lowest species richness values (Fig. 2a) across intermediate to high values of chlorophyll $a$.

In general, the average $S$ of epifaunal communities on local subtidal rock walls decreased from east to west across the North Atlantic Basin. For example, there was an average of $73 \pm 3.7$ (mean $\pm \mathrm{SE}, n=3$ ) species per local rock wall site in the eastern Atlantic (Channel Islands, UK) compared to $31 \pm 2.9(n=5)$ species in the western Atlantic (GOM) region (Table 1). Iceland sites were intermediate with an average richness of $52 \pm 3.7$ $(n=3)$ species. ANOVA on $\log _{10}$-transformed species richness values indicated a highly significant effect of region (GOM, Iceland, UK) on average $S$ per local site $\left(F_{2,8}=25.01, P=0.0004\right)$. Tukey's post-hoc tests indicated that average species richness in the Gulf of Maine was significantly lower $(P<0.0005)$ than that in the Channel Islands and Iceland $(P<0.007)$ which didn't differ. The ocean surface productivity conditions spanned a range of values from a low of $1.3 \mathrm{chl} a \mathrm{mg} / \mathrm{m}^{3}$ at a Channel Island site to maximum of $3.8 \mathrm{chl} a \mathrm{mg} / \mathrm{m}^{3}$ at a site in the Gulf of Maine (Table 1).

\section{St. Lawrence buoy epifauna}

A significant negative linear relationship was observed between species richness $(S)$ of epifaunal invertebrates and average chl $a$ on buoys at local spatial $(<20 \mathrm{~km})$ scales in the St. Lawrence Gulf and Estuary (Fig. 3a). Variability in chl $a$ explained up to $6 \%$ of the variability in $S$ at this scale. When the sites were merged at regional scales ( $200 \mathrm{~km}$; Fig. 3c), no significant relationships were observed. No significant trends occurred, however, when the data were corrected with salinity as a covariate using the residuals from a first step single regression between the salinity variable and $S$ (see Methods; Fig. 3b, d). There was a large range of chl $a$ values represented $\left(0.8-24.0 \mathrm{mg} / \mathrm{m}^{3}\right)$, which were higher in the estuarine (inner) zone than other more oceanic zones of the Gulf of St. Lawrence (Table 1). 
Subset with salinity data

All data
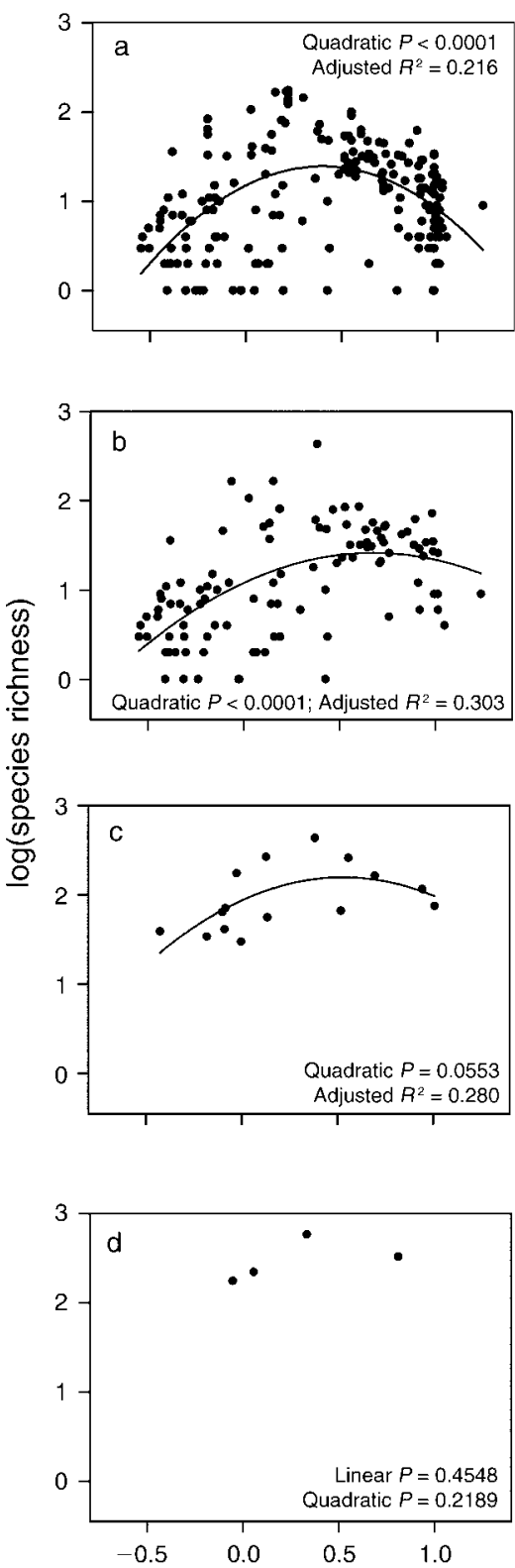

Without salinity covariate Local $<20 \mathrm{~km}$

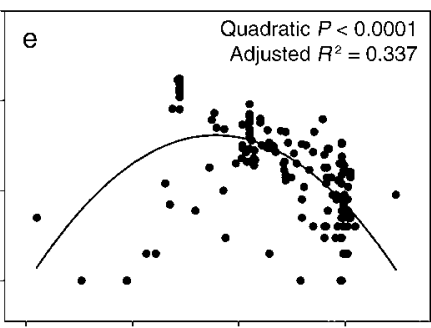

Landscape $\sim 20 \mathrm{~km}$

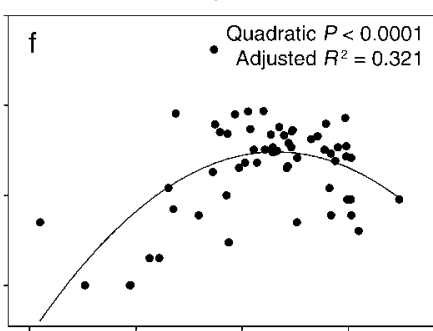

Regional $\sim 200 \mathrm{~km}$

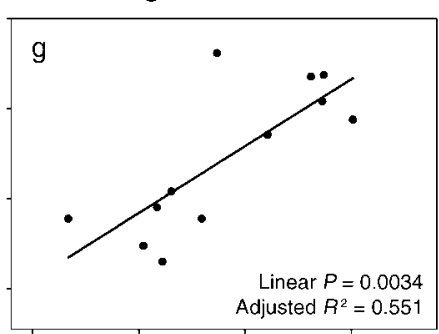

Continental $\sim 1000 \mathrm{~km}$

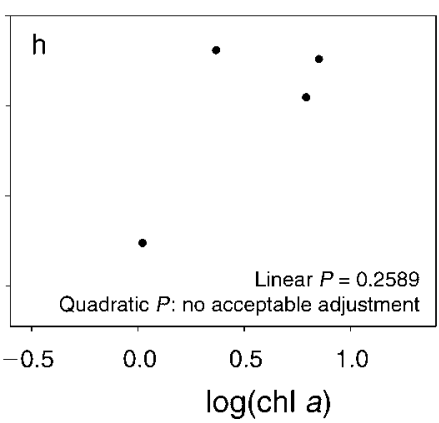

Corrected with salinity covariate
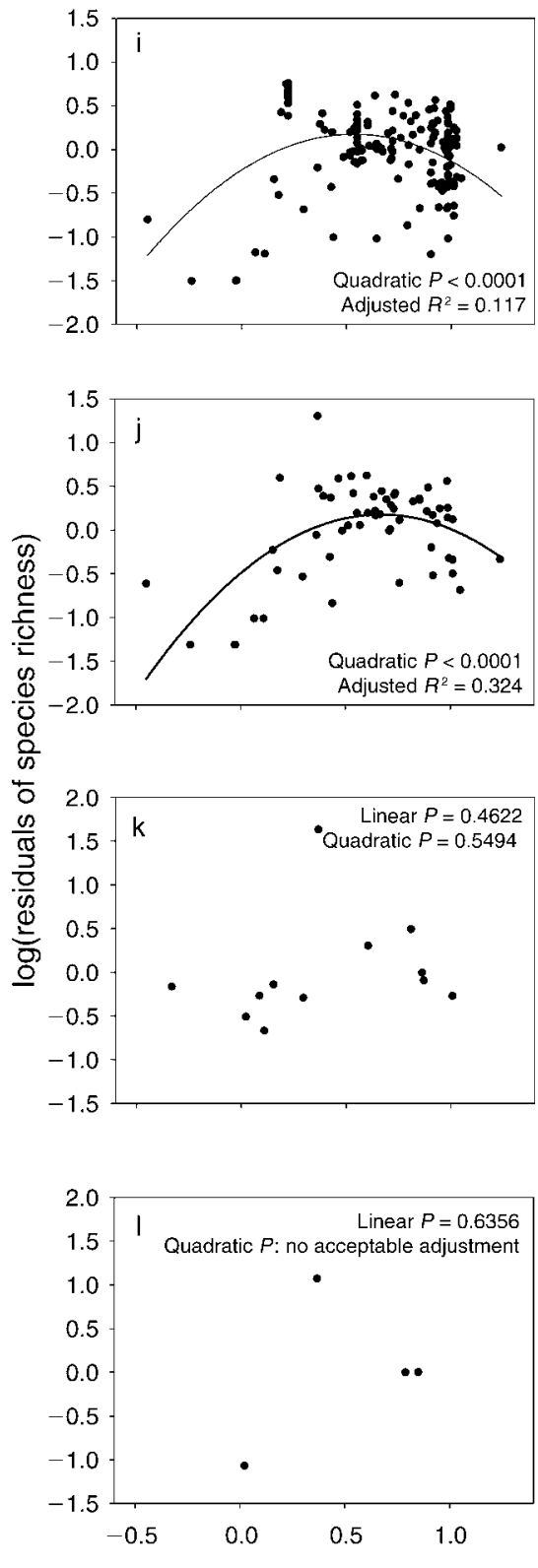

FIG. 4. Regression plots of the richness of Canadian Arctic soft-bottom species against average chlorophyll $a$ at various scales: local $(<20 \mathrm{~km})$, landscape $(>20 \mathrm{~km})$, regional $(\sim 200 \mathrm{~km})$, and continental $(>1000 \mathrm{~km})$. Plots showed separate analyses using $(\mathrm{a}-\mathrm{d})$ all stations and (e-1) subsets of stations with known salinity including species number $(\mathrm{e}-\mathrm{h})$ without and (i-l) with correction for salinity as a covariate. Plots $\mathrm{i}-1$ are regressions of the residuals from the regression of $\log _{10}$ (species number) on salinity against average chlorophyll $a$. See Table 2 for regression analyses.

\section{Canadian Arctic fauna}

A significant hump-shaped quadratic relationship occurred between species richness $(S)$ of macrobenthic invertebrates at local spatial scales and mean chl $a$ (Fig. 4a). Variability in chl $a$ explained $22 \%$ of the variability in $S$ at the local scale. When the data from each sites were pooled at a landscape scale of approximately $20 \mathrm{~km}$, the same significant hump-shaped relationship occurred, but the variability in chl $a$ explained more (30\%) of the variability in $S$ (Fig. 4b). A marginally significant hump-shaped quadratic relationship was also observed at a regional scale and 
Canadian Arctic, subset with density data

Local $<20 \mathrm{~km}$
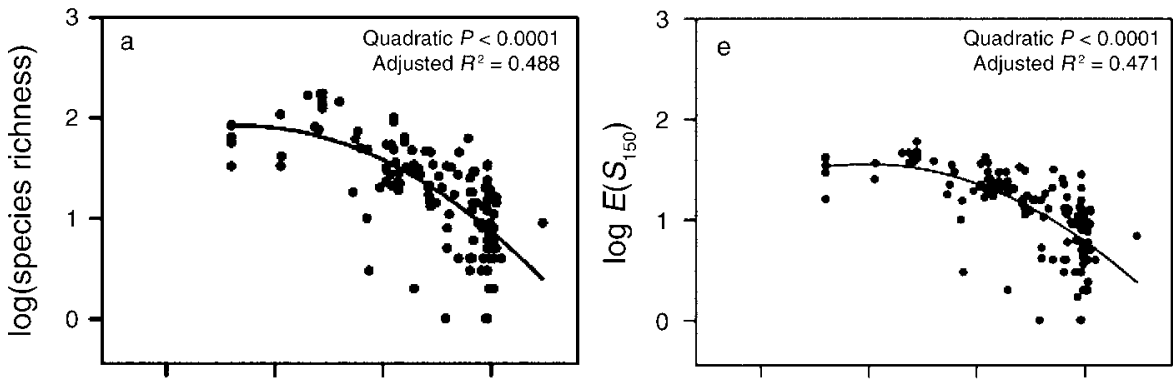

Landscape $\sim 20 \mathrm{~km}$
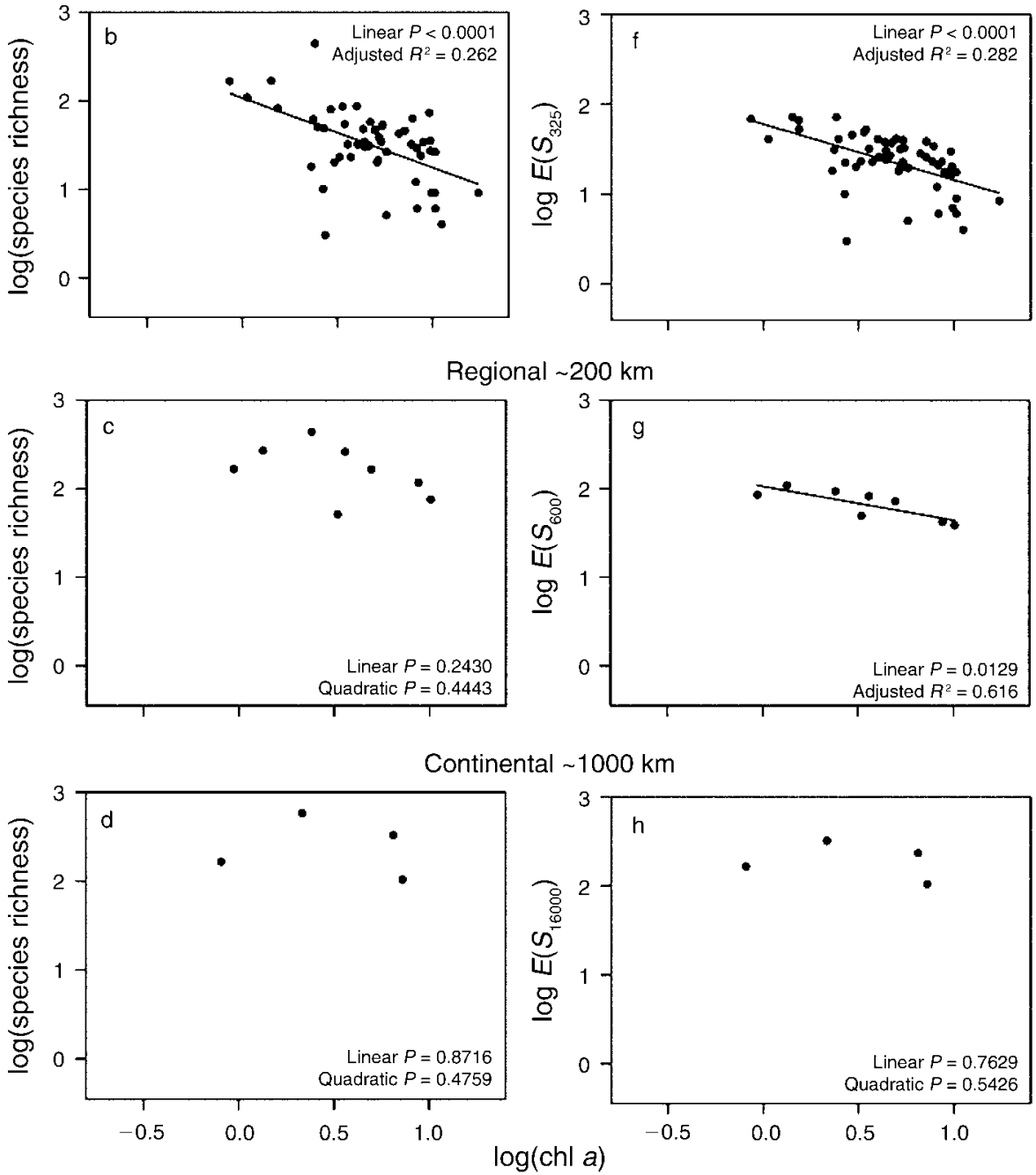

FIG. 5. Plotted regressions of chl $a$ and species richness of Arctic macrobenthos, comparing results using species richness and expected species number, $E\left(S_{n}\right)$. See Table 3 for regression analyses.

explained $28 \%$ of the variability in $S$ (Fig. 4 c). No significant relationships were found at continental scales $(\sim 1000 \mathrm{~km}$; Fig. 4d). The wide range of chl $a$ values $\left(0.3-17.3 \mathrm{mg} / \mathrm{m}^{3}\right)$ observed in the Canadian Arctic was similar to that from the Gulf of St. Lawrence and estuary (Table 1).
A subset of 156 of the 239 sites, for which bottom salinity data were available, were used to explore the effect of salinity on the relationship between $S$ and productivity. The data from this subset showed highly significant quadratic fits at local $\left(R^{2}=0.34 ; P<0.0001\right)$ and landscape $\left(R^{2}=0.32 ; P<0.0001\right)$ spatial scales 
TABLE 3. Results of different significant linear and polynomial regression models (shown in Fig. 5) to estimate observed species richness $\left(S_{\mathrm{obs}}\right)$ and rarefaction index, $E\left(S_{n}\right)$, using the mean chlorophyll $a(\mathrm{chl} a)$ variable

\begin{tabular}{lcccccccrrr}
\hline \hline & & & & & & \multicolumn{2}{c}{ MS } & \\
\cline { 6 - 8 } Plots & Type & Estimate & Intercept & Chl $a\left(\mathrm{mg} / \mathrm{m}^{3}\right)$ & $(\text { Chl } a)^{2}$ & df & Model & Total & $F$ & $P$ \\
\hline Fig. 5a & $\mathrm{Q}$ & $S_{\text {obs }}$ & $1.92 \pm 0.05$ & $-0.03 \pm 0.18$ & $-1.04 \pm 0.18$ & 2,172 & 14.37 & 0.29 & 118.27 & $<0.0001$ \\
Fig. 5b & $\mathrm{L}$ & $S_{\text {obs }}$ & $2.03 \pm 0.13$ & $-0.78 \pm 0.17$ & & 1,54 & 2.55 & 0.17 & 20.12 & $<0.0001$ \\
Fig. 5e & $\mathrm{Q}$ & $E\left(S_{150}\right)$ & $1.55 \pm 0.07$ & $-0.02 \pm 0.23$ & $-0.75 \pm 0.21$ & 2,141 & 5.50 & 0.16 & 63.77 & $<0.0001$ \\
Fig. 5f & $\mathrm{L}$ & $E\left(S_{325}\right)$ & $1.77 \pm 0.09$ & $-0.62 \pm 0.13$ & & 1,54 & 1.58 & 0.10 & 22.20 & $<0.0001$ \\
Fig. 5g & $\mathrm{L}$ & $E\left(S_{600}\right)$ & $2.03 \pm 0.07$ & $-0.38 \pm 0.11$ & & 1,7 & 0.13 & 0.03 & 12.21 & 0.0129 \\
\hline
\end{tabular}

Notes: Diversity (both species richness $\left[S_{\mathrm{obs}}\right]$ and rarefaction index $\left[E\left(S_{n}\right)\right]$ ) and chl $a$ were $\log _{10}$-transformed for use in the regression models. Type of regression: L, linear; Q, quadratic. Each regression coefficient $( \pm \mathrm{SE})$ and details of the ANOVAs are shown. Empty cells indicate that the variable was not included in the model.

(Fig. 4e, f) while a positive linear relationship $\left(R^{2}=0.55\right.$; $P<0.0034)$ was observed at the regional scale. No relationship was observed at the largest continental spatial scales $(>1000 \mathrm{~km})$. When these relationships were corrected for the influence of salinity by using the residuals from a first step single regression between the salinity variable and $S$, a hump-shaped relationship occurred only at local $\left(R^{2}=0.12\right.$, Fig. 4i) and landscape spatial scales $\left(R^{2}=0.32\right.$, Fig. $\left.4 \mathrm{j}\right)$.

Since the Arctic data set was composed of data where some stations were assessed with various sampling efforts, regression analyses were also done using a subset of data for which density data were available (see Fig. 5), on species richness standardized for abundances (as suggested by Gotelli and Colwell 2001). Except at the regional scale $(200 \mathrm{~km})$, no differences of shape or type of relations between diversity measure and chlorophyll $a$ were observed when using observed species richness (Fig. 5a-d) and the rarefaction index (Fig. 5e-h). The observed differences were likely due to underestimation of richness from a few regions' sites with high regional richness. Indeed, the number of individuals $(n=600)$ used in the rarefaction index remain too low to assess adequately high values of regional richness (cf. Fig. $5 \mathrm{c}, \mathrm{g}$ ). This reduces the dispersion of the points and residuals in the regression, affecting the outcome of the analyses. The similarity of results between the two indices (species richness and rarefaction index) validates the general use of observed species richness for the Arctic data set.

\section{Discussion}

The relationship between the species richness of macrobenthic invertebrate communities and the productivity of the overlying water column varied according to systems and scale (grain). A variety of functions between productivity and species richness occurred, from significant negative linear relationships in epifaunal communities to quadratic hump-shaped relationships in the Arctic epifaunal and infaunal communities. Although it is impossible to elucidate causation from quantitative correlative studies such as this one, it is possible to assess the evidence for different causal processes underlying the productivity-richness patterns observed and to eliminate some where data are inconsistent with the predictions of theory. In this sense, this work identifies potential mechanisms of diversity regulation in different community types and at different scales for future hypothesis testing.

As with many macroecological studies, sample size decreased as data were aggregated from small (local) to large (continental) spatial scales. This may reduce the ability to detect significant relationships between species richness and chl $a$ at the larger (regional and continental) scales. Yet, significant relationships occurred in the wall epifauna data at the smallest and largest spatial scales. In the Arctic data, the fit of the polynomial (quadratic) regression increased when the data were aggregated from local to larger landscape scales (Fig. 4a, b) and similarly, from quadratic fits at the local scale to linear fits at regional scales (Fig 4e, g). Although regressions based on three data points must be viewed with caution (Fig. 2d), we consider that the scaling patterns observed are not solely influenced by the reduction of sample size as scale increases.

\section{Negative linear relationships}

A general pattern observed in the epifaunal communities on subtidal rock walls and to a lesser degree on navigation buoys, was that species richness was negatively related to productivity. These patterns occurred within conditions of fully marine salinity (subtidal epifauna) as well as across a salinity gradient (buoy epifauna in the St. Lawrence Gulf and Estuary, 21.530.5 PSU) although the St. Lawrence regression was nonsignificant when corrected for salinity. A variety of mechanisms could account for monotonically decreasing diversity with productivity including (1) high disturbance at high productivity sites, (2) competitive dominance at high productivity, (3) covarying environmental stress along the productivity gradient, (4) larger individuals at high-productivity sites, (5) high consumer pressure at high productivity sites, and (6) declining rarity with increased productivity. We were able to evaluate the evidence for several of these mechanisms.

First, the disturbance mechanism assumes that there are sufficient differences in physical disturbance among the local rock wall sites to influence levels of epifaunal invertebrate diversity. All 11 rock wall sites were fully exposed to oceanic swells and waves, however, so it is 
unlikely that there were large enough differences in disturbance among sites to drive the observed trend of declining diversity with productivity.

The second mechanism, spatial competition is a likely cause of diversity decline under conditions of high productivity, as strong competitive interactions occur in rock wall habitats (Sebens 1986). In the Gulf of Maine (GOM) which had the highest productivity, a competitively dominant sponge, Hymedesmia spp. can depress the diversity of epifaunal communities on rock walls (Hill et al. 2004), and it occurred at $60 \%$ of the GOM sites.

The third mechanism, environmental (salinity) stress clearly covaries with productivity in its effect on epifaunal species richness in the Estuary and Gulf of St. Lawrence as the negative linear regression was significant when both chl $a$ and salinity variables were included in the model. The relationship was however, rendered non-significant when the salinity effect was removed by residual analyses. The co-varying effect on richness was likely due to low species richness in inner estuarine areas of the St. Lawrence where the highest chl $a$ concentrations and the lowest salinities (21.5-26.5 PSU) occurred. Salinity gradients and freshwater discharge in estuaries are important factors controlling species richness in general (Remane and Schlieper 1971, Smith and Witman 1999, Crain et al. 2004). For example, Ardisson and Bourget (1992) observed a steady decrease in species richness over 12 years in the St. Lawrence system along the gradient of decreasing salinity. Salinity gradients and freshwater discharge are also important in the Canadian Arctic (Cusson et al. 2007). Our finding that salinity is an important covarying factor with productivity urges caution for future studies of the effect of productivity on species diversity in coastal areas where varying salinity may be a common confounding factor. Indeed, the St. Lawrence system is influenced by the second largest freshwater discharge $\left(11900 \mathrm{~m}^{3} / \mathrm{s}\right)$ in North America (El-Sabh and Silverberg 1990). In this context, the freshwater discharge could be considered as a significant environmental stress for organisms living in the surface layer such as those sampled on the buoys, and in estuaries and fjords (Witman and Grange 1998) as low salinity kills marine invertebrates adapted to higher, more marine salinities (Remane and Schlieper 1971).

The fourth mechanism, patterns of body size, may contribute to the negative linear relationships in the epifaunal communities if larger individuals are more common at highly productive sites, then samples taken there would contain fewer individuals and possibly fewer species. However, we speculate that body size differences are not contributing to the overall pattern. For example, Ardisson and Bourget (1991) observed the largest maximum sizes of mussels on navigational buoys on the North shore of the Gaspé peninsula, which is distant from the low-salinity and high-productivity (chl $a$ ) areas in the inner St. Lawrence estuary.
The fifth mechanism, consumer pressure by sea urchins, partly influenced the negative linear functions by reducing epifaunal richness at sites with intermediate to high chl $a$ values in the GOM. Yet the negative linear relationship was significant at the local scale even when the few urchin-impacted sites were omitted from the analysis, suggesting the importance of surface productivity in driving the relationship. We did not evaluate the rarity mechanism.

Given the mechanisms that can be discounted, the emerging picture for the subtidal epifaunal communities on rock walls is that productivity may depress species richness at sites particularly where urchin predation is unimportant, via competitive dominance of sponges. This suggests that top-down (predation) as well as bottom-up (food, nutrients) processes may influence diversity in rock wall habitats. Environmental stress in the form of low salinity is apparently a major factor limiting diversity at highly productive sites in the St. Lawrence system. Fewer differences were observed in the Arctic data between the results with and without the salinity effect (cf. Fig. 4e-h and $\mathrm{i}-1$ ), suggesting that while regionally important (cf. Fig. 4g, k), salinity may have less influence on species richness in the Arctic than in the St. Lawrence system.

\section{Unimodal, hump-shaped relationships}

A hump-shaped function between productivity and diversity codominated with negative linear functions as the most commonly supported models in the marine communities analyzed. All of the hump-shaped relationships occurred in the Canadian Arctic faunal communities. Why is the hump-shaped model, dubbed the "intermediate productivity hypothesis," (Scheiner and Jones 2002), so widespread? Classic models indicate that the primacy of food resources (no food, no food web, no species) explains the rising limb of the parabola (Huston 1999). In general, quadratic functions suggest trade offs between different causal processes with one process dominating at low levels of productivity, which then gives way to another process at high range of productivity. Grime (1973) reasoned that a mode would be produced at intermediate levels of productivity or biomass where the largest number of species coexist between extremes of productivity or environmental stress. The form of the productivity diversity relationship may depend on the range of productivities sampled (Rosenzweig 1995, Huston 1999) with linear functions changing to hump-shaped patterns as the range of productivity is expanded. We explored this possibility with the rock wall epifauna data, which had the smallest range of chl $a$, by adding dummy chl $a(x)$ and species richness $(y)$ values to the original data to examine the conditions required to make the negative linear fit switch to a significant quadratic regression. Significant quadratic regressions (parabolic or hump-shaped pattern) were obtained with the epifaunal data when extremely low values of average species richness $(S=1, S=5)$ and 
productivity ( $\mathrm{chl} a=0.5,1.0 \mathrm{mg} / \mathrm{m}^{3}$ ) were added to the original data. These values are unrealistic, however, as sampling 18-36 photo quadrats on rock walls in the GOM, the region of lowest species richness, has never revealed communities this species poor, with average species richness values as low as one or five species per $0.25 \mathrm{~m}^{2}$ (J. Witman, unpublished data). Consequently, we consider that the negative linear pattern found in epifaunal communities is real, and not part of a parabola that would be revealed analyzing a broader range of chl $a$ values.

The prevalence of hump-shaped relationships observed in the Canadian arctic fauna suggests that productivity is important to the diversity of filter-feeding bivalve communities, which composed a majority of these macrobenthic communities (Cusson et al. 2007). A potential mechanism driving positive diversity-productivity relationships may occur when increased productivity is accompanied by an increase in rare resources required by specialist species (Abrams 1995). In this case, diversity may increase with productivity as the number of rare specialist species increases. An investigation of a corollary of this mechanism, that rarity increases with productivity, was not supported by the Canadian Arctic data since the number of species contributing less than $10 \%, 5 \%$, and $1 \%$ of the total abundance did not vary with mean chl $a$ (M. Cusson and P. Archambault, unpublished data).

The mechanisms invoked to explain the descending limb of the hump-shaped model are similar to explanations for the negative linear model and include competitive dominance at high productivity, increasing environmental stress, high consumer pressure, and/or severe disturbance at high productivity (Grime 1973, Scheiner and Jones 2002). Grebmeier and Barry (1991) argued that benthic community diversity in the Arctic environment varies not only as a result of food availability but also in response to disturbance. Levels of physical disturbance could be high along the Arctic coast (ice scouring and fluvial input, see Piepenburg [2005] for a review). In this study, little information is available to evaluate any of these mechanisms besides environmental stress (low salinity), which our covariate regression analyses suggest has an important influence on the descending limb of the hump-shaped productivity-richness relationships observed in the Arctic communities (Fig. 4). These results confirm aspects of Grime's (1973) model. Indeed, salinity is an influential environmental variable affecting Arctic species richness (Cusson et al. 2007).

\section{Role of community context}

An unexpected finding was that the form of productivity-richness relationships differed by community type with negative linear relationships occurring only in sessile epifaunal communities and hump-shaped relationships found in the mixed epifaunal and infaunal communities of the Canadian Arctic. While many factors capable of influencing diversity patterns differ between these two systems, this result may reflect varying strengths of competition and how it interacts with productivity in the different systems. Space is at a premium in nearly two-dimensional encrusting epifaunal communities (Jackson 1977, Sebens 1986). A reduction of diversity caused by competitive dominants (Paine 1966) utilizing high productivity may be more likely in epifaunal than in infaunal communities where the more three dimensional habitat can be partitioned with less obvious impacts on diversity (Peterson 1979, Black and Peterson 1988). This might also explain why productivity was negatively related to richness over the entire range of chl $a$ in epifaunal communities but not in Arctic macrobenthic communities which contained substantial numbers of infaunal species.

\section{Alternative hypotheses}

Few ecologists would invoke a single explanation to account for local patterns of species richness observed across large spatial scales, as regional (historical) and local (ecological) processes interact to produce the levels of diversity observed (Ricklefs 1987, Huston 1999, Witman et al. 2004). A major alternate hypothesis to environmental or ecological factors (i.e., productivity) driving contemporary patterns of diversity, particularly on large scales spanning several biogeographic regions, is that the patterns may stem from evolutionary (historical) processes (Ricklefs 1987, Huston 1999). Historical processes, such as biotic interchanges and extinctions influencing the size of the regional species pool are seldom considered as determinants of local species number in investigations of species energy or other ecological effects (but see Hawkins et al. 2003a). Yet the species richness of local marine benthic communities is often predicted by the number of species in the regional pool (Karlson et al. 2004, Witman et al. 2004, Russell et al. 2006), suggesting that regional pool effects as well as productivity should be investigated in the spatially extensive data sets (subtidal epifauna, Canadian Arctic benthos) presented in this paper. Indeed, historical processes may contribute to the gradient of decreasing epifaunal species richness observed in rock wall communities from east to west across the North Atlantic. Lower diversity of marine fauna on the North American vs. the European side of the Atlantic has been noted in several groups including molluscs, barnacles (Vermeij 1978, Ingolfsson 1992, Vermeij et al. 2008), and algae (South 1987). Vermeij et al. (2008) found that this trans-Atlantic diversity pattern belies a single explanation, such as a shorter time for colonization and diversity build up after the last glaciation on the North American side (Ingolfsson 1992), because the trans-Atlantic diversity differences pre-date Pleistocene glacial periods by millions of years.

We suggest that long-term differences in productivity are a viable alternative or complementary hypothesis to the influence of historical factors in explaining trans- 
Atlantic diversity differences. In the Canadian Arctic, Cusson et al. (2007) considered that the history of environmental conditions is an important factor determining faunal distribution and richness. Regional variation in salinity in areas influenced by large rivers (such as Mackenzie River) in addition to the presence of unproductive cold Arctic water masses may account for the low observed species richness in the western Arctic (Curtis 1975).

An alternative ecological hypothesis for productivitydiversity relationships documented here concerns the sequence of community assembly (Fukami and Morin 2003). For example, the sequence of community assembly by invertebrates recruiting on navigational buoys in this study differs from one area to another. Considering that many species regulate their spawning with chl $a$ concentration (Starr et al. 1990) and water temperature (Olive 1995) and that settlement-recruitment processes differ along the estuarine gradient, this hypothesis merits investigation. Water temperature and the timing of the spring phytoplankton bloom is not uniform in the St. Lawrence (Levasseur et al 1984, Therriault and Levasseur 1985). This heterogeneity of environmental characteristics could change the relation among species initially entering the community. Investigating the history of community assembly as it influences diversity along productivity gradients in all three systems should prove insightful.

In general, more attention needs to be paid to the interactive effects of several mechanisms when studying productivity-diversity relationships (Huston 1999, Kondoh 2001, Worm et al. 2002, Worm and Duffy 2003, Michalet et al. 2006). Although unable to formally test the mechanistic underpinnings of the patterns revealed in this study, we recognize the potential for interacting processes to produce diversity patterns. For instance, the interaction of competitive ability and environmental stress could play out to impact diversity in the St. Lawrence system if mussels dominated habitats with stressful low salinity conditions, since mussels are adapted to euryhaline conditions and capable of lowering diversity via competitive overgrowth (Suchanek 1986). In GOM subtidal communities, epifaunal diversity is influenced by consumers (urchins) and by productivity, apparently via effects on competitive dominance, highlighting the potential for interacting effects (consumers, resources [Worm et al. 2002]) to shape productivity-diversity relationships.

\section{Spatial scaling of productivity-diversity relationships}

In plant communities of Wisconsin, the effect of increasing the spatial grain on productivity-diversity relationships was to change the relationship from humpshaped at the smallest (local) grain, to negative linear at intermediate grain and ultimately, to a U-shaped pattern at the largest grain (Scheiner and Jones 2002). Similarly, Chase and Leibold's (2002) experiments in pond communities revealed a switch from hump-shaped patterns at local grain to positive linear relationships at regional grains. Thus, there is a tendancy for humpshaped patterns to predominate at small to intermediate spatial scales. The scale dependence of the productivitydiversity relationship may arise from dissimilarity in local species composition that increases with productivity (Chase and Leibold 2002). The parallels with our results for marine benthic communities are that humpshaped and linear patterns were most common at the smallest spatial scales (local and landscape). An emergent theme demonstrated by the occurrence of hump-shaped and linear functions at the smaller scales, is that processes that limit the diversity of communities via the direct or indirect effects of productivity are most common at smaller spatial scales. This is logical given that biological interactions tend to play out on smaller local spatial scales (Huston 1999). For example, a decline in the intensity of competition with increasing spatial grain could explain why quadratic and negative linear relationships occurred at small spatial scales. Clearly, the mechanisms underlying scale-dependent changes in the productivity diversity relationships identified here warrant future research.

\section{ACKNOWLEDGMENTS}

We thank Cliff Cunningham and the U.S. National Science Foundation (NSF DEB-RCN 0130275) for bringing the CORONA group together for fruitful collaborations. J. Witman's diversity research was supported by NSF Biological Oceanography, the National Undersea Research Program (Avery Point, Connecticut), personal funds, and by CORONA meeting travel. Thanks to S. Daly for diving assistance and to A. Lehman of Sark Diving Services for logistical support in the Channel Islands, Paul Jonssson for help in Iceland, and A. Chiriboga for assistance with photo quadrats. Thanks to $\mathrm{M}$. Hardy, P. Robichaud, and L. de Montety for help collecting data from the navigational buoys, and for lab analyses. The navigational buoys data are part of the Benthic Biodiversity on Buoys project funded by Department of Fisheries and Oceans Canada to P. Archambault. The Arctic database collection was funded by Canadian Arctic Shelf Exchange Study (CASES, NSERC) grants to P. Archambault and M. Cusson. P. Archambault's project was also supported by the Department of Fisheries and Oceans, Canada. We thank Bruce Monger for help with accessing the mapped SeaWiFS chl $a$ data. N. Mieszkowska was supported by funding from NASA grant NNG04GE43G and by NOAA NA04NOS4780264. Many thanks to Brian Helmuth and Cliff Cunningham for stimulating discussion during the initial phases of this research. We also thank two anonymous reviewers for their constructive comments.

\section{Literature Cited}

Abrams, P. A. 1995. Monotonic or unimodal diversityproductivity gradients: what does competition theory predict? Ecology 76:2019-2027.

Archambault, P., K. Banwell, and A. J. Underwood. 2001. Temporal variation in the structure of intertidal assemblages following the removal of sewage. Marine Ecology Progress Series 222:51-62.

Ardisson, P.-L., and E. Bourget. 1991. Abundance, growth, and production estimation of the blue mussel Mytilus edulis on moored navigation buoys in the Estuary and northwestern Gulf of St. Lawrence. Canadian Journal of Fisheries and Aquatic Sciences 48:2408-2419. 
Ardisson, P.-L., and E. Bourget. 1992. Large-scale ecological patterns: discontinuous distribution of marine benthic epifauna. Marine Ecology Progress Series 83:15-34.

Atkinson, E. G., and J. W. Wacasey. 1989a. Benthic invertebrates collected from Hudson Bay, Canada, 1953 to 1965. Canadian Data Report of Fisheries and Aquatic Sciences No. 744.

Atkinson, E. G., and J. W. Wacasey. 1989b. Benthic invertebrates collected from the western Canadian Arctic, 1951 to 1985. Canadian Data Report of Fisheries and Aquatic Sciences No. 745.

Black, R., and C. H. Peterson. 1988. Absence of preemption and interference competition for space between large suspension-feeding bivalves and smaller macroinvertebrates. Journal of Experimental Marine Biology and Ecology 120: 183-198.

Brown, S. 1981. A comparison of the structure, primary productivity, and transpiration of cypress ecosystems in Florida. Ecological Monographs 51:403-427.

Brunel, P., L. Bossé, and G. Lamarche. 1998. Catalogue of the marine invertebrates of the Estuary and Gulf of SaintLawrence. Canadian Special Publication of Fisheries and Aquatic Sciences 126. NRC Research Press, Ottawa, Ontario, Canada.

Chase, J. M., and M. A. Leibold. 2002. Spatial scale dictates the productivity-biodiversity relationship. Nature 416:427-430.

Chown, S. L., and K. J. Gaston. 1999. Patterns in procellariiform diversity as a test for species-energy theory in marine systems. Evolutionary Ecology Research 1:365-373.

Colwell, R. K. 1997. EstimateS: statistical estimation of species richness and shared species from samples. Version 7.0. User's guide and application. University of Connecticut, Storrs, Connecticut, USA.

Crain, C. M., B. R. Silliman, S. L. Bertness, and M. D. Bertness. 2004. Physical and biotic drivers of plant distribution across estuarine salinity gradients. Ecology 85:2539-2549.

Currie, D. J. 1991. Energy and large scale patterns of animal and plant species richness. American Naturalist 137:27-49.

Curtis, M. A. 1975. The marine benthos of Arctic and subArctic continental shelves. Polar Research 17:595-626.

Cusson, M., P. Archambault, and A. Aitken. 2007. Biodiversity of benthic assemblages on the Arctic continental shelf: historical data from Canada. Marine Ecology Progress Series 331:291-304.

El-Sabh, M. I., and N. Silverberg. 1990. Oceanography of a large-scale estuarine system: the St. Lawrence. Coastal and Estuarine Studies 39:1-434.

Fraser, R. H., and D. J. Currie. 1996. The species richnessenergy hypothesis in a system where historical factors are thought to prevail: coral reefs. American Naturalist 148: $138-159$.

Fukami, T., and P. J. Morin. 2003. Productivity-biodiversity relationships depend on the history of community assembly. Nature 424:423-426.

Gotelli, N. J., and R. K. Colwell. 2001. Quantifying biodiversity: procedures and pitfalls in the measurement and comparison of species richness. Ecology Letters 4:379-391.

Gregg, W. W., and N. W. Casey. 2004. Global and regional evaluation of the SeaWiFS chlorophyll data set. Remote Sensing of the Environment 93:463-479.

Grebmeier, J. M., and J. P. Barry. 1991. The influence of oceanographic processes on pelagic-benthic coupling in polar regions: a benthic perspective. Journal of Marine Systems 2: 495-518.

Grime, J. P. 1973. Competitive exclusion in herbaceous vegetation. Nature 242:344-347.

Hall, S. J., S. A. Gray, and Z. L. Hammett. 2000. Biodiversityproductivity relations: an experimental evaluation of mechanisms. Oecologia 122:545-555.

Hawkins, B. A., J. A. F. Diniz-Filho, and E. E. Porter. $2003 a$. Productivity and history as predictors of the latitudinal gradient of terrestrial birds. Ecology 84:1608-1623.
Hawkins, B. A., R. Field, H. V. Cornell, D. J. Currie, J.-F. Guegan, D. M. Kaufman, J. T. Kerr, G. Mittelbach, T. Oberdorff, E. M. O'Brien, E. E. Porter, and J. R. G. Turner. 2003b. Energy, water, and broad-scale geographic patterns of species richness. Ecology 84:3105-3117.

Hill, M. F., J. D. Witman, and H. Caswell. 2004. Markov chain analysis of succession in a rocky subtidal community. The American Naturalist 164:E46-E61.

Hurlbert, S. H. 1971. Nonconcept of species diversity: critique and alternative parameters. Ecology 52:577-586.

Huston, M. A. 1999. Local processes and regional patterns: appropriate scales for understanding variation in the diversity of plants and animals. Oikos 86:393-401.

Ingolfsson, A. 1992. The origin of the rocky shore fauna of Iceland and the Canadian Maritimes. Journal of Biogeography 19:705-712.

Jackson, J.B.C. 1977. Competition on marine hard substrata: the adaptive significance of solitary and colonial strategies. American Naturalist 111:743-767.

Jara, V. C., J. H. S. Miyamoto, B. A. P. Da Gama, M. Molis, M. Wahl, and R. C. Pereira. 2006. Limited evidence of interactive disturbance and nutrient effects on the diversity of macrobenthic assemblages. Marine Ecology Progress Series 308:37-48.

Karlson, R. H., H. V. Cornell, and T. P. Hughes. 2004. Coral communities are regionally enriched along an oceanic biodiversity gradient. Nature 429:867-870.

Kondoh, M. 2001. Unifying the relationships of species richness to productivity and disturbance. Proceedings of the Royal Society of London B 268:269-271.

Levasseur, M., J.-C. Therriault, and L. Legendre. 1984. Hierarchical control of phytoplankton succession by physical factors. Marine Ecology Progress Series 19:211-222.

Lubinsky, I. 1980. Marine bivalve molluscs of the Canadian Central and Eastern Arctic: faunal composition and zoogeography. Canadian Bulletin of Fisheries and Aquatic Science 207:1-73.

MacLaren MAREX. 1978. Report on marine benthic invertebrates of the southern Davis Strait and Ungava Bay for Imperial Oil Limited, Aquitaine Company of Canada Limited and Canada Cities Service Limited. MacLaren MAREX, Dartmouth, Nova Scotia, Canada.

May, R. M. 1974. Ecosystem properties in randomly fluctuating environments. Progress in Theoretical Biology 3:1-50.

Michalet, R., R. W. Brooker, L. A. Cavieres, Z. Kikvidze, C. J. Lortie, F. J. Pugnaire, A. Valente-Banuet, and R. M. Callaway. 2006. Do biotic interactions shape both sides of the humped-back model of species richness in plant communities? Ecology Letters 9:767-773.

Mittelbach, G. G., C. F. Steiner, S. M. Scheiner, K. L. Gross, H. L. Reynolds, R. B. Waide, M. R. Willig, S. I. Dodson, and L. Gough. 2001. What is the observed relationship between species richness and productivity? Ecology 82:2381-2396.

Olive, P. J. W. 1995. Annual breeding cycles in marine invertebrates and environmental temperature: probing the proximate ultimate causes of reproductive synchrony. Journal of Thermal Biology 20:79-90.

Paine, R. T. 1966. Food web complexity and species diversity. American Naturalist 100:65-75.

Peterson, C. H. 1979. Predation, competitive exclusion, and diversity in the soft-sediment benthic communities of estuaries and lagoons. Pages 223-264 in R. J. Livingston, editor. Ecological processes in coastal and marine systems. Plenum Press, New York, New York, USA.

Piepenburg, D. 2005. Recent research on Arctic benthos: common notions need to be revisited. Polar Biology 28: 733-755.

Preston, F. W. 1962. The canonical distribution of commonness and rarity. Ecology 43:185-215.

Quinn, G. P., and M. J. Keough. 2002. Experimental design and data analysis for biologists. Cambridge University Press, Cambridge, UK. 
Remane, A., and C. Schlieper. 1971. Biology of brackish water. Wiley-Interscience, New York, New York, USA.

Rex, M. A. 1981. Community structure in the deep sea benthos. Annual Review of Ecology and Systematics 12:331-353.

Ricklefs, R. E. 1987. Community diversity: relative roles of local and regional processes. Science 235:167-171.

Rosenzweig, M. L. 1995. Species diversity in space and time. Cambridge University Press, Cambridge, UK.

Rosenzweig, M. L., and Z. Abramsky. 1993. How are diversity and productivity related? Pages $52-65$ in R. E. Ricklefs and D. Schluter, editors. Species diversity in ecological communities: historical and geographical perspectives. University of Chicago Press, Chicago, Illinois, USA.

Roy, K., D. Jablonski, J. W. Valentine, and G. Rosenberg. 1998. Marine latitudinal diversity gradients: tests of causal hypotheses. Proceedings of the National Academy of Sciences (USA) 95:3699-3702.

Russell, R., S. A. Wood, G. Allison, and B. A. Menge. 2006. Scale, environment and trophic status: the context dependency of community saturation in rocky intertidal communities. American Naturalist 167:E158-E170.

Rutherford, S., S. D'Hondt, and W. Prell. 1999. Environmental controls on the geographic distribution of zooplankton diversity. Nature 400:749-753.

Sanders, H. L. 1968. Marine benthic diversity: a comparative study. American Naturalist 102:243-282.

Scheiner, S. M., and S. Jones. 2002. Diversity, productivity and scale in Wisconsin vegetation. Evolutionary Ecology Research 4:1097-1117.

Sebens, K. P. 1986. Spatial relationships among encrusting marine organisms in the New England subtidal zone. Ecological Monographs 56:73-96.

Smith, F., and J. D. Witman. 1999. Species diversity in subtidal landscapes: maintenance by physical processes and larval recruitment. Ecology 80:51-69.

Sokal, R. R., and J. F. Rohlf. 1981. Biometry. Third edition. W.H. Freeman and Company, New York, New York, USA.

South, G. R. 1987. Biogeography of the benthic marine algae of the North Atlantic Ocean: an overview. Helgoländer Meeresuntersuchungen 41:273-282.

Starr, M., J. H. Himmelman, and J.-C. Therriault. 1990. Direct coupling of marine invertebrate spawning with phytoplankton blooms. Science 247:1071-1074.

Stewart, P. L. 1983. Measurements of benthic macroinvertebrates standing crop from the Canadian continental shelf and slope of Southern Davis Strait and Ungava Bay. Canadian Journal of Fisheries and Aquatics Sciences 40:652-658.

Stewart, P. L., P. Pocklington, and R. A. Cunjak. 1985. Distribution, abundance and diversity of benthic macroinvertebrates on the Canadian continental shelf and slope of Southern Davis Strait and Ungava Bay. Arctic 38:281-291.

Suchanek, T. H. 1986. Mussels and their role in structuring rocky shore communities. Pages 70-96 in G. Moore and R. Seed, editors. The ecology of rocky coasts. Columbia University Press, New York, New York, USA.

Svensson, J. R., M. Lindegarth, M. Siccha, M. Lenz, M. Molis, M. Wahl, and H. Pavia. 2007. Maximum species richness at intermediate frequencies of disturbance: consistency among levels of productivity. Ecology 88:830-838.

Therriault, J.-C., and M. Levasseur. 1985. Control of phytoplankton production in the lower St. Lawrence Estuary: light and freshwater runoff. Naturaliste Canadien 112:77-96.

Thomas, A. C., D. W. Townsend, and R. Weatherbee. 2003. Satellite-measured phytoplankton variability in the Gulf of Maine. Continental Shelf Research 23:971-989.
Vermeij, G. J. 1978. Biogeography and adaptation: patterns of marine life. Harvard University Press, Cambridge, Massachusetts, USA.

Vermeij, G. J., G. P. Dietl, and D. G. Reid. 2008. The transAtlantic history of diversity and body size in ecological guilds. Ecology 89(Supplement):S39-S52.

Wacasey, J. W., E. G. Atkinson, L. Derick, and A. Weinstein. 1977. Zoobenthos data from the southern Beaufort Sea, 1971-1975. Fisheries and Marine Service Research and Development Technical Report No. 41.

Wacasey, J. W., E. G. Atkinson, and L. Glasspoole. 1979. Zoobenthos data from upper Frobisher Bay, 1967-1973. Canadian Data Report of Fisheries and Aquatic Sciences No. 164.

Wacasey, J. W., E. G. Atkinson, and L. Glasspoole. 1980. Zoobenthos data from inshore stations of upper Frobisher Bay, 1969-1976. Canadian Data Report of Fisheries and Aquatic Sciences No. 205.

Wacasey, J. W., E. G. Atkinson, and L. Kinlough. 1976. Zoobenthos data from James Bay, 1959, 1974. Fisheries and Marine Service Research and Development Technical Report No. 661 .

Whittaker, R. J., M. B. Araujo, J. Paul, R. J. Ladle, J. E. M. Watson, and K. J. Willis. 2005. Conservation biogeography: assessment and prospect. Diversity and Distributions 11: 3-23.

Whittaker, R. J., and E. Heegaard. 2003. What is the observed relationship between species richness and productivity? Ecology 84:3384-3390.

Whittaker, R. J., K. J. Willis, and R. Field. 2001. Scale and species richness: towards a general, hierarchical theory of species diversity. Journal of Biogeography 28:453-470.

Wiens, J. A. 1989. Spatial scaling in ecology. Functional Ecology 3:385-397.

Witman, J. D. 1985. Refuges, biological disturbance, and rocky subtidal community structure in New England. Ecological Monographs 55:421-445.

Witman, J. D., R. J. Etter, and F. Smith. 2004. The relationship between regional and local species diversity in marine benthic communities: a global perspective. Proceedings of the National Academy of Sciences (USA) 101:156644-15669.

Witman, J. D., and K. R. Grange. 1998. Links between rain, salinity and predation in a rocky subtidal community. Ecology 79:2429-2447.

Worm, B., and J. E. Duffy. 2003. Biodiversity, productivity and stability in real food webs. Trends in Ecology and Evolution 18:628-632.

Worm, B., H. R. Lotze, H. Hildebrand, and U. Sommer. 2002. Consumer versus resources control of species diversity and ecosystem functioning. Nature 417:848-851.

Worm, B., M. Sandow, A. Oschlies, H. K. Lotze, and R. A. Myers. 2005. Global patterns of predator diversity in the open oceans. Science 309:1365-1369.

Wright, D. H. 1983. Species-energy theory: an extension of species-area theory. Oikos 41:496-506.

Wright, D. H., D. J. Currie, and B. A. Maurer. 1993. Energy supply and patterns of species richness on local and regional scales. Pages 66-74 in R. E. Ricklefs and D. Schluter, editors. Species diversity in ecological communities: historical and geographical perspectives. University of Chicago Press, Chicago, Illinois, USA.

Zar, J. H. 1999. Biostatistical analysis. Fourth edition. Prentice Hall, Upper Saddle River, New Jersey, USA.

\section{SUPPLEMENT}

Original data used for analyzing relationships between species richness and chlorophyll $a$ by linear and polynomial regression (Ecological Archives E089-186-S1). 